\title{
Understanding the Concept of Job Satisfaction, Measurements, Theories and its Significance in the Recent Organizational Environment: A Theoretical Framework
}

\author{
Wasif Ali \\ Doctoral Research Scholar, \\ Faculty of Commerce, Banaras Hindu University, \\ Varanasi, Uttar Pradesh, India,
}

\begin{abstract}
Job or work is an important aspect of an individual's life and it occupies a lot of personal and professional time compared to any other activity. Satisfaction is the pleasure felt after a need is fulfilled. One would suppose a person is satisfied when his or her expectations or desires or requirements have been met. Job satisfaction describes how much extent an individual is pleased, comfortable or satisfied with his or her job. It is a pleasurable or positive emotional state resulting from the appraisal of one's job or job experiences. In current organisations Job Satisfaction is a crucial subject of attention which is very considered by the higher authorities, policy makers and top executives because this issue is related to many other significant and important issues of organisations. Employees are the core assets and key part of any organisations by which all means of production are handled. As a human being this is human nature that employee are satisfied or dissatisfied what work they are assigned. This is the prime objective of the organizations that they should make and implement such type of policies that can make an employee to satisfy with his/her job which is assigned to them. It is clear from previous studies that how Job Satisfaction is important for any organisations. It is very important issue nowadays when organizations are facing with many types of employee related problems and challenges i.e. organizational performance, organizational commitment, employee turnover, employee productivity etc. Keeping in view the significance and importance of Job Satisfaction in organizations, scholar had endeavored to elaborate the construct of Job Satisfaction, its measurements, theories and its significance in current organizational issues. The research paper is theoretical in nature and subjects have been clarifies with the help of concerned literatures and previous studies regarding this area.
\end{abstract}

Key Words: Job Satisfaction, Organizational Performance, Employee Turnover, Organizational Commitment, Employee Productivity.

\section{CONCEPT OF JOB, SATISFACTION AND JOB SATISFACTION}

Job or work is an important aspect of an individual's life and it occupies a lot of personal and professional time compared to any other activity. It provides the financial basis for a person's life (Santhapparaj \& Alam, 2005). Warr Cook \& Wall (1979) have defined the job and differentiate it with work as job to the task undertaken in a particular setting whereas, work is taken to cover job more generally. Job can be looked at as the means used to achieve personal goals relating to ones career. On the other hand satisfaction is the contentment felt after a need is fulfilled (Robbins \& Stephen, 1998). Satisfaction, as defined by Thorndike \& Barnhart (1979), is the "fulfillment of conditions or desires". Therefore, one would suppose a person is satisfied 
when his or her expectations or desires or requirements have been met. Job satisfaction describes how much extent an individual is pleased, comfortable or satisfied with his or her job. It is a relatively modern term since in earlier centuries the jobs available to a particular person were often predetermined by the occupation of that person's parent. A person's Job Satisfaction level is influenced by many factors. Some of these factors include the level of pay and benefits, the alleged fairness of the promotion system within a company, the quality of the working conditions, leadership and social relationships, the work itself, the diversity of tasks involved, the opportunity and challenge the job generates, and the clearness of the job description/requirements). The happier people are within their job, the more satisfied they are said to be. Job satisfaction is not the same as motivation, although it is clearly linked with other issues. Job design aims to enhance job satisfaction and performance methods include job rotation, job enlargement and job enrichment. Other influences on satisfaction include the management style and culture, employee involvement, empowerment and autonomous workgroups. Job satisfaction is a very important attribute which is frequently measured by organizations (Kabir \& Parveen, 2011).

The issue of Job Satisfaction has initiated with the beginning of scientific management by F.W. Taylor in 1911 when he introduced piece rate system and linked employees' affluence with organization's prosperity through enhancing employee productivity (Ghafoor, 2012). The early use of scientific management by industries significantly increased productivity because workers were forced to work as a faster way. However workers became bushed and dissatisfied, thus leaving with the new question to answer regarding job satisfaction. But the concept of Job Satisfaction was much highlighted when Hawthorne Studies were conducted in late 1920s and early 1930s. These studies were accomplished by Elton Mayo of the Harvard Business School, at the Hawthorne plant of the Western Electric Company in Chicago. The Hawthorne studies were firstly designed to study the effect of working condition on workers' productivity, but the emphasis soon moved to the study of attitude. The finding of these studies provides strong evidence that people work for purpose other than pay which lined the way for researchers to investigate other factors in job satisfaction. After that Hoppock (1935) began to analyze job satisfaction systematically and identified a range of factors contributing to job satisfaction.

\section{JOB SATISFACTION IN THE VIEW OF PROMINENT SCHOLARS}

Hoppock (1935) describes the construct of job satisfaction as being any number of psychological, physiological and environmental circumstances that causes a person to say that I am satisfied with my job. Vroom in his view focuses on the role of employees in the workplace. He defined Job satisfaction as affective orientation on the part of individuals, towards work roles which they are present occupying (Vroom, 1964). According to Locke (1976) Job Satisfaction is "a pleasurable or positive emotional state resulting from the appraisal of one's job or job experiences". As defined by Feldman \& Arnold (1983) Job satisfaction as the amount of overall positive affect (or feelings) that individuals have towards their jobs. In the opinion of Davis et al. (1985) Job satisfaction represents a combination of positive or negative feelings that workers have towards their work. Meanwhile, when a worker employed in a business organization, brings with it the needs, desires and experiences which determinates expectations that he has dismissed. Job satisfaction represents the extent to which expectations are and match the real awards. Job satisfaction is closely linked to that individual's behavior in the work place (Davis et al., 1985).

Andrew (1988) stated that job satisfaction is the amount of pleasure or contentment associated with a job. Spector defines job satisfaction is the extent to which people like (satisfaction) or dislike (dissatisfaction) this jobs According to this definition Job satisfaction is 
a general or global affective reaction that individual goal about their job (Spector, 1997). In the view of Statt (2004) Job satisfaction can be defined as the extent to which a worker is content with the rewards he or she gets out of his or her job, particularly in terms of intrinsic motivation (Statt, 2004). Kreitner \& Kinicki (2004) defines Job Satisfaction as "an affective and emotional response to various facets of one's job". Mullins (2005) defines this construct as a complex and multifaceted concept which can mean different things to different people. Job satisfaction is usually linked with motivation, but the nature of this relationship is not clear. Satisfaction is not the same as motivation. Job satisfaction is more of an attitude, an internal state. It could, for example, be associated with a personal feeling of achievement, either quantitative or qualitative (Mullins, 2005). According to Armstrong's (2006) definition job Satisfaction refers to the attitude and feeling people have about their work positive and favourable towards the job indicates job satisfaction, negative and unfavourable attitude towards the job indicates job dissatisfaction (Armstrong, 2006).

About Job Satisfaction words of (Kaliski, 2007) are "Job satisfaction is a worker's sense of achievement and success on the job. It is generally perceived to be directly linked to productivity as well as to personal well-being. Job satisfaction implies doing a job one enjoys, doing it well and being rewarded for one's efforts. Job satisfaction further implies enthusiasm and happiness with one's work. Job satisfaction is the key ingredient that leads to recognition, income, promotion, and the achievement of other goals that lead to a feeling of fulfillment" (Kaliski, 2007). George et al. (2008) concluded that Job satisfaction is the collection of feeling and beliefs that people have about their current job. People's levels of degrees of job satisfaction can range from extreme satisfaction to extreme dissatisfaction. In addition to having attitudes about their jobs as a whole. People also can have attitudes about various aspects of their jobs such as the kind of work they do, their coworkers, supervisors or subordinates and their pay (George et al., 2008). According to Aziri (2008) job satisfaction represents a feeling that appears as a result of the perception that the job enables the material and psychological needs (Aziri, 2008).

\section{MEASURES OF JOB SATISFACTION (SPECTOR, 1997)}

There are various types of measures available provided by many scholars and authorities to assess the Job Satisfaction of any individual. A brief description of some important measures of job satisfaction is as follows:

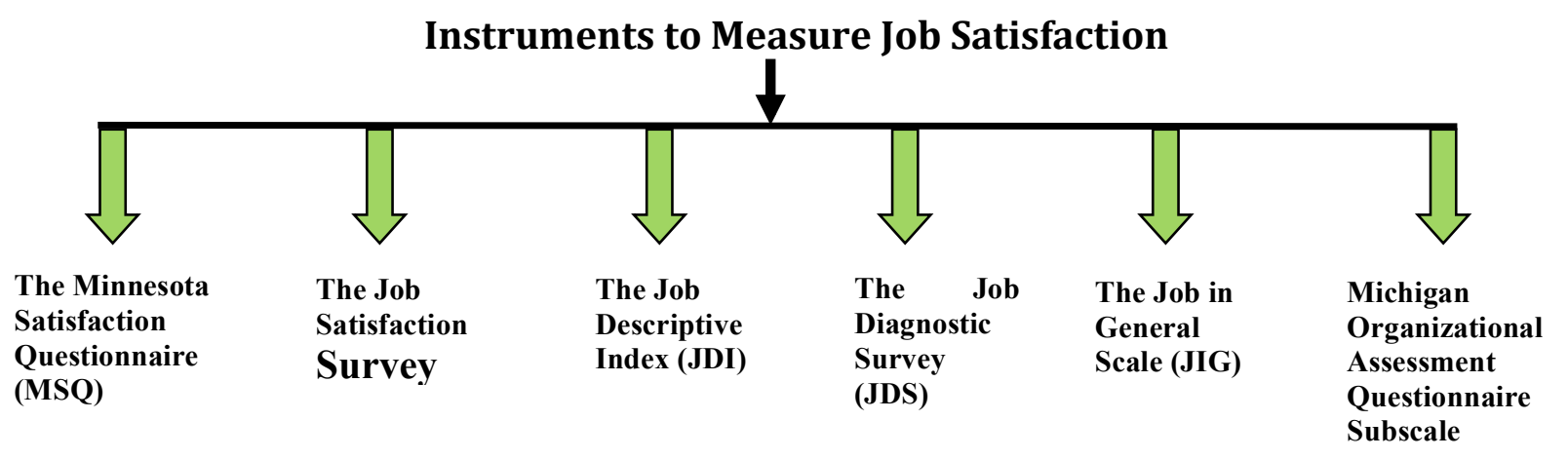

\section{The Minnesota Satisfaction Questionnaire (MSQ)}

The Minnesota Satisfaction Questionnaire (MSQ; Weiss et al., 1967) is a job satisfaction scale that has been very poplar and is easy in applicability among researchers. The MSQ contains in two forms, a 100-item long version and 20-item short form. It covers 20 facets, many of which are more specific than other satisfaction scales. Most of the researcher who use the short form 
combines all the items into a single total score or compute extrinsic and intrinsic satisfaction subscales from subset of items. Extrinsic satisfaction concerns aspect of work that has little to do with the job task or work itself, such as pay. Intrinsic satisfaction refers to the nature of job task themselves and how people feel about the work they do. Subscales, which have better reliabilities than individual item $\mathrm{s}$, are better preferred.

\section{The Job Satisfaction Survey}

The Job Satisfaction Survey (JSS; Spector, 1997) assesses 9 facets of Job Satisfaction, as well as overall satisfaction. The Scale Contains 36 items and uses a summated rating scale format. This format is most accepted for job satisfaction scales. The format of JSS makes it relatively easy to modify. Each of the nine facet subscales contains four items, and a total satisfaction score can be computed by combining all of the items.

\section{The Job Descriptive Index}

The Job Descriptive Index (JDI; Smith, Kendall, \& Hullin, 1969) has probably been the most popular facet scale among organizational researchers. It also may have been most carefully developed and validated. The scale assesses five facets:
a. Work
b. Pay
c. Promotion
d. Supervision
e. Coworkers

The entire scale includes 72 items with either 9 or 18 items per subscales. Each item is an evaluative adjective or short expression that is descriptive of the job. Responses are "Yes" or "No". For each facet scale, a brief clarification is provided, followed by the items relating to that facet. Both favorable or positive and unfavorable or negative worded items are offered in the scale.

\section{The job Diagnostic Survey}

The job Diagnostic Survey (JDS; Hackman \& Oldham, 1975) is a measure that was developed to study the impact of job characteristics on the people. It includes the subscale to measure the nature of the job and job tasks, motivation, personality, psychological states,(cognition and feelings about job tasks), and reaction to the job. The JDS is discussed here as a facet measure because it covers several areas of job satisfaction, specially growth, pay security, social, and supervision, as well as global satisfaction. The format for the facet items is a 7 point Likert scale ranging from "Extremely dissatisfaction to "Extremely Satisfied". The forms for global satisfaction subscale are a 7 point ranging from "Disagree Strongly" to "Agree Strongly".

\section{The Job in General Scale (JIG)}

The Job in General Scale (JIG; Ironson et al., 1989) was designed to evaluate overall job Satisfaction rather than facet. Its format is similar to JDI, and it contains 18 items. Each item is an adjective and short phrase about the job in general rather than a facet. The total score is a combination of all items. Ironson et al. argue that overall job satisfaction is not the total of individual facets and that should not be assessed with a general scale like the JIG. The JIG uses three response choices. For each item, respondents are asked if they agree (yes), aren't sure (?) or disagree (no). Negatively worded items are reverse-scored, and the total score is the sum of the responses.

\section{Michigan Organizational Assessment Questionnaire Subscale}

Michigan Organizational Assessment Questionnaire Subscale contains a three item overall satisfaction subscale (Cammann et al., 1979). The scale is simple and short, which makes it 
ideal for use in questionnaire that holds many scales. For each item there are seven response choices: "Strongly disagree to "Strongly Agree". The responses are numbered from 1 to 7, respectively, but the second item is adversely scored. The items are totaled to yield an overall job satisfaction score.

\section{THEORIES OF JOB SATISFACTION}

Scholars had offered various types of views and opinion regarding the theories of Job Satisfaction. In the followings, theories of Job Satisfaction presented by various intellectuals are mentioned:

\section{Maslow's Need hierarchy Theory:}

One theory of human motivation that has received a enormous deal of publicity in the past was developed by Abraham Maslow. Maslow (1943) conceptualized that people are driven by unsatisfied needs that shape their behavior. In his theory Maslow classified human needs into five categories that ascend in a definite order as follows:

1. Physiological needs

2. Safety and security needs

3. Belonging and love needs

4. Esteem needs and

5. Self- actualization needs.

He suggested that after a person has moved from a lower to a higher level of need, the higher level needs suppose to be less importance since they have been adequately met. At a lower tier, essential life sustaining requirements as food, clothing and shelter were identified. Next were physical and security need were considered, thirdly social acceptance, belongings and love, fourth was self esteem needs and recognition by people and finally fifth was self actualization need such as personal autonomy and self direction. According to Maslow the needs of an individual subsists in a coherent order and that the basic lower level requirements must be satisfied before these higher level, then once the basic needs are fulfilled, they no longer serve as motivators for the individual. The more a job allows for development and attainment of higher level needs, the more likely the individual is to report satisfaction with his or her job.

\section{Herzberg's Motivation/ Hygiene Theory (Two factors theory)}

This theory was developed by Frederick Herzberg, Manusner, Peterson and Capwell (1959) in extension to Maslow's work. Herzberg and his colleagues revealed in their theory that job satisfiers were linked with the job content and job dissatisfaction were associated to job context. The satisfiers were worded as motivators while dissatisfiers were termed as hygiene factors. While hygiene factors were responsible for preventing dissatisfaction, motivators were essential to keep employee satisfy. Factors such as achievement, recognition, responsibility etc, are satisfiers, the presence of which causes satisfaction but their absence does not result in dissatisfaction. On the other hand, factors such as supervision, salary, working conditions etc are dissatisfiers, the absence of which causes dissatisfaction. Their presence however, does not result in job satisfaction.

\section{Alderfer's ERG Theory}

Clayton Alderfer's (1969) theory is referred to as ERG theory and is based on the three needs: Existence, Relatedness and Growth. Existence is referred as providing individuals physiological and safety needs. Relatedness is the desire to keep good interpersonal relationships to which Maslow marked as social and esteem needs. Growth needs are an intrinsic need for personal 
development based on the self actualization needs of Maslow. According to ERG theory a person's background or cultural surroundings may cause the relatedness requirements to outweigh to unfulfilled existence needs. It is also possible that the intensity of growth needs will enhance with an increase in the degree to which they are satisfied.

\section{Vroom's Expectancy Theory}

Victor Vroom (1964) proposed an expectancy theory which is also known as VIE theory to explain work motivation. In his theory he point out three variables as:

- Valance

- Instrumentality

- Expectancy

Vroom's theory of Job Satisfaction was equivalent in that it looked at the interaction between personal and workplace variables; however he also incorporated the elements of workers' expectation in his theory. The core of this theory is that if workers put forth much effort and give better and enhanced performance at work, then they will be compensated accordingly. Discrepancies that arise between expected compensation and actual outcome leads to dissatisfaction. If employees receive less than they expect or otherwise feel as if they have been treated unduly, then dissatisfaction may occur. Conversely, overcompensation may also lead to dissatisfaction and employee may experience feeling of guiltiness. In Vroom's formula each variable is given a probability value, and when all three factors are high, employees will be more satisfied and have more motivation, If any of the factors are low, work performance and employee motivation will decline.

\section{Porter-Lawler Model (Needs Fulfillment Theory)}

The Porter-Lawler model was developed by Lyman W. Porter and Edward E. Lawler III (1967). It was an expansion of Vroom's Expectancy theory. In their model Porte-Lawler endeavored to explore the complex relationship between motivation, satisfaction and performance. They pointed out that efforts made by any employees did not directly result in performance. Their model was comprehensive explanation of work motivation. The model describes that performance in an organization is depended on these factors;

- Employee have willingness to perform a work and should be motivates to do a task;

- Motivation alone cannot ensure successful performance of a task. The employee should also have the capabilities and skill to perform a job successfully.

- The employee has a clear perception of his role in the organizations and an accurate knowledge of the job requirements.

The porter-Lawler Motivation Model is as follows: 


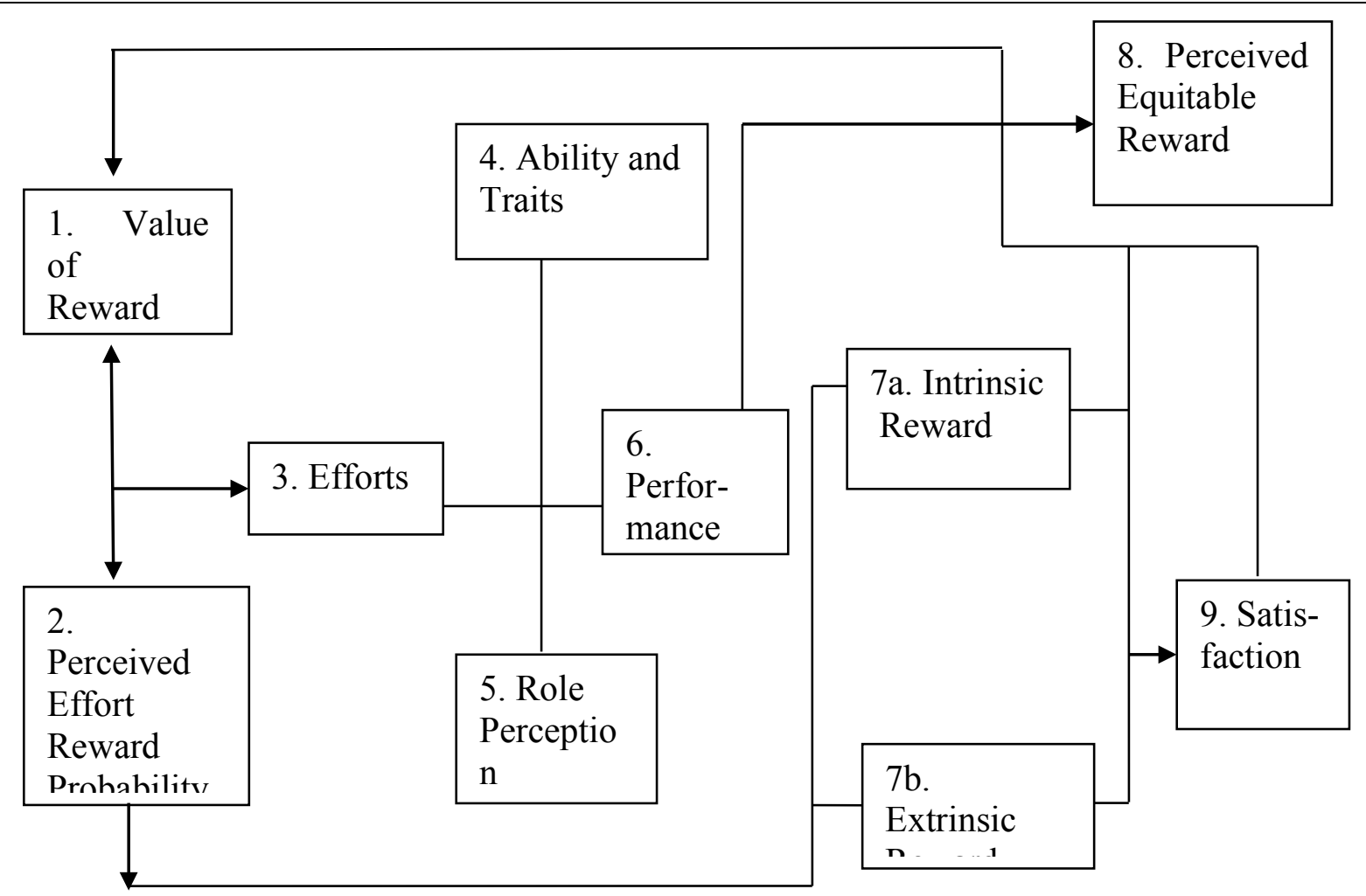

Fig: 1 the porter-Lawler Motivation Model

Source: ICFAI Book, Organization Behavior, p. 136

\section{Equity Theory}

James Stacy Adams (1963) propounded the equity theory. Equity theory describes that the degree of equity or inequity perceived by an employee with reference to his work situation plays a key part in work performance and satisfaction. Equity theory was based on three main hypotheses. First that people develop beliefs about what comprises a fair and equitable return for their contribution to their jobs. Secondly, people tend to compare what they perceive to be the exchange they have with their employers to that which they perceive, coworkers have with their employers. Thirdly, equity theory holds that when people believe that their own treatment is not equitable in comparison to their colleagues, with whom they are comparing themselves, they feel inequity. According this theory Equity is represented schematically as follows:

Figure: 2 Showing Equity in Employees

$\frac{\text { Persons' Outcome }}{\text { Persons' Input }}=\frac{\text { Others' Outcome }}{\text { Others' Input }}$


Figure: 3 Showing Inequity in Employees

Persons' Outcome

Persons' Input

Persons' Outcome

Persons' Input
Others' Outcome

Others' Input

Others' Outcome

Others' Input

Source: ICFAI Book, Organization Behavior, p. 138

\section{JOB CHARACTERISTICS MODEL}

Hackman \& Oldham (1975) introduced the Job Characteristics Model, which is widely used as a framework of study how particular job characteristics affect job outcomes, including job satisfaction. The model states that there are five core job characteristics (skill variety, task identity, task significance, autonomy and feedback) which impact three critical psychological states (experienced meaningfulness, experienced responsibility for outcomes, and knowledge of the actual results), in turn influencing work outcomes (job satisfaction, absenteeism, work motivation, etc.). The five core job characteristics can be combined to form a motivating potential score (MPS) for a job which can be used as an index of how likely a job is to affect an employee's attitude and behavior.

\section{RELEVANCE OF JOB SATISFACTION IN CURRENT ORGANIZATIONAL ISSUES}

Job Satisfaction is very important and significant issue nowadays in organizations and higher authorities, policy makers and top executives are paying more attention to this issue that how to make employees of their organization more satisfied because job satisfaction is related with some other important organizational issues which directly or indirectly influences the organization's goals. Here, relationship of Job Satisfaction with some organizational issues had been clarified with the help of some literatures.

\section{Job Satisfaction and Organizational Performance}

In their research Carroll, Keflas \& Watson (1964) revealed that satisfaction and productivity are crucially related to each other and in each one of them affects the other. They concluded that performance stimulates to more effort because of high supposed expectancy.After evaluating many previous studies literature Smith and Cranny (1968) concluded that there is a positive relationship among job satisfaction and employee performance as well as effort, commitment and intention. In another study conducted by western electric studies (1966) the outcomes of Relay Assembly test room showed that there is a strong relationship between job satisfaction and employee productivity and it was also suggested that if an employee job satisfaction is increased his productivity will also increase. Porter and Lowler (1969) concluded that satisfaction will influence a worker's effort, and that increased satisfaction from performance will possibly helps to increase expectations of performance which will lead to rewards. In the literature there is evidence that Job Satisfaction is related with Job Performance of employees in variety of organizational settings. David, Joseph \& William (1970) suggest that the type of reward system under which workers perform strongly influence the satisfaction performance relationship. In his study Cummings (1970) identified three major issues with reference to this relationship. Satisfaction leads performance, performance causes satisfaction and rewards leads to both performance and satisfaction. Kornhanuser \& Sharp (1976) have carried out more than thirty studies to identify the relationship between 
satisfaction and performance in industrial sector. Out of their all studies, many researches revealed that there was a positive relationship between job satisfaction and employee performance but contrary in their researches Katzell, Barret \& Porker (1952) concluded that job satisfaction was neither related with turnover nor with quality of production The effort carries to effective performance, which again leads to satisfaction in essential relationship. Mirvis \& Lawer (1977) in his study revealed conclusive findings regarding association between job satisfaction and employee performance. Endeavoring to measure the performance of bank tellers with regard of cash shortages, they opinioned that satisfied tellers were less likely to show shortages and less likely to leave their jobs which shows the less employee turnover rate.

\section{Job Satisfaction and Organizational Commitment}

Many studies have acknowledged that job satisfaction is an important predictor and antecedent of organizational commitment and it has an impact on organizational commitment in different way (Porter et al., 1974; Mottaz, 1987; Williams \& Anderson, 1991; Vanderberg \& Lance, 1992; Young, Worchel \& Woehr, 1998; Testa, 2001). There is also evidence on the basis of the conclusions of many researches that job satisfaction leads to commitment among workers (Vedamanickam, 2001; Samaratunge, 2003; Kanter, 2004; McNulty \& Ferlie, 2004; George \& Jones, 2008; Mohamadkhani \& Nasiri, 2012; Kahtani, 2012). Job satisfaction acts as a dominant variable to the relationship between co-workers' relationship and organizational commitment (Lin and Lin, 2011). Ilhami (2012) revealed and concluded that high levels of job satisfaction results in higher commitment. In another study extrinsic, intrinsic and general satisfaction is found to be associated to organizational commitment (Samavi, 2011; Hashmi \& Naqvi, 2012). The findings of the study carried out by Azeem \& Akhtar (2014) demonstrates a moderate level of job satisfaction and organizational commitment among the Saudi employees working in public sector organizations. Job satisfaction facets and organizational commitment were found to be positively related. As far as the demographic variables are concerned, only tenure was found significantly related to commitment. It was also found that Job satisfaction facets and job tenure were the significant predictors of organizational commitment. In a study conducted by Mohammad \& Eleswed (2013) which aim was to examine the relationship between job satisfaction and organizational commitment and to investigate the impact of demographics key variables on job satisfaction and organizational commitment in a private financial institution in the Kingdom of Bahrain was found a positive relationship between job satisfaction and organizational commitment.

\section{Job Satisfaction and Employee Turnover}

In current business environment organizations are facing a crucial problem of high employee turnover rate. Turnover is process in which employee leave the organization and have to be replaced. Like absenteeism, turnover is related to job dissatisfaction. Excessive turnover can be a very costly problem, one with a major impact on productivity. But cost is not the only reason turnover is important. Lengthy training times, interrupted schedules, additional overtime, mistakes and not having knowledgeable employees in place are some of the frustrations related with excessive turnover. Turnover is a severe trouble in part because of its relationship to decreased quality of care and extra expense for employers (Larrahee et al., 2003). In their research Lambert et al. (2001) revealed that employee turnover can be predicted using comprehensive measures of job satisfaction and also concluded that high job satisfaction is related to low employee turnover. In his study Silverthorne (2004) found that if an employee is better fitted in organization he will be better satisfied with his job and ultimately it will increase the organizational commitment and also decrease the turnover rate. The research findings of (Lambert et al., 2001) shows that job satisfaction is associated with employee engagement. In their research they found that the employees who are much satisfied with their 
job are more engaged in their work in comparison to employees who are not much satisfied with their job. Because of low level of employee engagement, employees are withdrawing with their jobs in the form of voluntary turnover. Literature also shows that scholars i.e. Benko \& Weisberg (2007), Becker (2007) also accepted that job satisfaction and employee turnover intention are inversely related. They suggested that for realistic and performance reasons, it is necessary that organizations should identify explicit factors related to employees' job satisfaction, especially in competitive, cut throat and fast paced business environments

\section{Job Satisfaction and Organizational Productivity}

Various scholars have shown that job satisfaction is positively related with worker productivity and negatively associated with employee turnover (Egan et al., 2004; Silverthorne, 2004). It was concluded in researches greater job satisfaction is associated with greater productivity, so more satisfied employees ought to be more productive, in comparison to lesser satisfied employees (Silverthorne, 2004). Gupta \& Joshi (2008) has argued the impact and the connection between the job contentment and work inspiration for the employees in thi research. He found that productivity in the work of an employee is result of satisfaction and productivity can be taken as indicator of satisfaction. Employees have to spend most of their time at workplace and need satisfaction at that place.

\section{CONCLUSION}

Job Satisfaction has its significance in organizations and it was always a subject of relevance and attention among scholars, academicians and corporate persons. In overall conclusion it can be revealed that the concept Job Satisfaction is related to an individual's psychological as well as physiological pleasure towards any job performed by him/her. Job Satisfaction is elaborated by various scholars in different ways and many types of measurements and theories have been proposed by intellectuals regarding Job Satisfaction. Finally Job Satisfaction has a significant relationship and impact over many types of important organizational issues i.e. Organizational Performance, Organizational Commitment, Employee Turnover and Organizational Productivity.

\section{References}

Adams, J. S. (1963). Toward an Understanding of Inequity. Journal of Abnormal and Social Psychology, 67, 422-36.

Alderfer, Clayton P. (1969). An Empirical Test of a New Theory of Human Needs. Organizational Behavior and Human Performance, 4(2), 1 42-175.

Andrew, J. B. (1988). the Practice of Supervision, New Delhi, Universal Bookstall.

Armstrong, M. (2006). A Handbook of Human Resource Management Practice, 10th Ed, London: Kogan Page Publishing.

Azeem, S. M., \& Akhtar, N. (2014). Job Satisfaction and Organizational Commitment among Public Sector Employees in Saudi Arabia. International Journal of Business and Social Science, 5(7), 127-133.

Aziri B. (2011). Job Satisfaction: A Literature Review. Management Research and Practice, 3(4), 77-86.

Becker, F. (2007). Organizational Ecology and Knowledge Networks. California Management Review, 49(2), $42-61$.

Benko, C. \& Weisberg, A. (2007). Implementing a Corporate Career Lattice: The Mass Career Customization Model. Strategy \& Leadership, 35(5), 29-36.

Cammann, C., Fichman, M., Jenkins, D., \& Klesh, J. (1979). The Michigan Organizational Assessment Questionnaire. Unpublished manuscript, University of Michigan, Ann Arbor.

Carroll, S., Keflas, R., \& Watson, C. (1964). Job Satisfaction and Productivity. Irwin: Illinois.

Cummings, K. (1970). Job satisfaction and Performance. Journal of Social Psychology, 141(5), 541-563. 
Ali, W. (2016). Understanding the Concept of Job Satisfaction, Measurements, Theories and its Significance in the Recent Organizational Environment: A Theoretical Framework. Archives of Business Research, 4(1), 100-111.

Davis, K., \& Nestrom, J. W. (1985). Human Behavior at work: Organizational Behavior, 7th edition, McGraw Hill, New York.

David, F, Joseph, \& William, K. (1970). Job satisfaction Commitment. Irwin: Illions.

Egan, T. M., Yang, B., \& Bartlett, K. R. (2004). The effects of organizational learning culture and job satisfaction on motivation to transfer learning and turnover intention. Human Resource Development Quarterly, 15(3), 279-301.

Feldman, D. C., \& Arnold, H. J. (1983). Managing Individual and Group Behavior in Organizations. New York; McGraw-Hill.

George, J., \& Jones, G. (2008). Understanding and managing organizational behavior. (5th ed.). Upper Saddle River, New Jersey: Pearson Prentice Hall.

Ghafoor, M. M. (2012). Role of Demographic Characteristics on Job satisfaction. Far East Journal of Psychology and Business, 6(1), 30-45.

Gupta, K., Shashi, \& Rosy, J. (2008). Human Resource Management, Pg. (20.9 to 20.17).

Hackman, J. R., \& Oldham, G. R. (1975). Development of the Job Diagnostic Survey. Journal of Appliued Psychology, $60,159-170$.

Hashmi, M. S. \& Naqvi, I. H. (2012). Investigating Organizational Commitment as the Outcome of Job Satisfaction: A Study of Banking Sector of Pakistan. International Journal of Learning and Development, 2(4), 22-35.

Herzberg, F., Mausner, B., \& Snyderman, B. S. (1959). The Motivation to Work. New York, NY: Wiley \& Sons.

Hoppock, R. (1935). Job Satisfaction. New York: Harper Brothers.

İlhami, Y. (2012). Examining the Relationships among Job Satisfaction, Organizational Commitment, and Turnover Intention: An Empirical Study. International Journal of Business and Management, 7(20), 44-58.

Ironson, G. H., Smith, P. C., Brannick, M. T., Gibson, W. M., \& Paul, K. B. (1989). Constitution of a Job in General Scale: A Comparison of global, composite, and specific measures. Journal of Applied Psychology, 74, $193-200$.

June H. Larrahee. (2003). Predicting Registered Nurse Job Satisfaction and Intent to Leave. Journal of Nursing Administration, 33(5), 271.

Kahtani, N .S. (2012). A study of relationship between demographical variables, organizational structure and social interaction with organizational commitment among employees of Saudi Arabia. International Journal of Trade and Commerce, 1(1), 11-22.

Kaliski, B. S. (2007). Encyclopedia of Business and Finance, Second edition, Thompson Gale, Detroit.

Kanter, R. M. (2004). The middle manager as innovator. Harvard Business Review, 82(7/8), 150-161.

Katzell, A., Barret, C. \& Porker (1952). Motivation and Labour Turnove. Irwin Inc. Illions.

Kornhanuser, F. \& Sharp, P. (1976) Job Satisfaction and Motivation of Employees in Industrial Sector. Journal of Social Psychology, 145, 323-342.

Kreitner, R. \& Kinicki, A. (1995). Organizational Behavior, Third Edition, Richard D. Irwin. INC, USA.

Lawler, E. E. III \& Porter, L.W. (1967). The Effect of Performance on Job Satisfaction, Industrial Relations, 20-28.

Lin, S. C., \& Lin, J. J. (2011). Impacts of coworkers' relationships on organizational Commitment and intervening effects of job satisfaction. African Journal of Business Management, 5(8), 3396-3409.

Locke, E. A. (1976). The nature and causes of job satisfaction. In M. D. Dunnette (Ed.), Handbook of industrial and organizational psychology, Chicago: Rand McNally.

Maslow, A. H., (1943). A Theory of Human Motivation. Psychological Review, 50(4), 370-396.

Mirvis, C., \& Lawer (1977). Job Satisfaction and Job Performance in Bank Tellers. Journal of Social Psychology, 133 (4), 564-587.

Mohamadkhani, K., \& Nasiri, M. L. (2012). Emotional Intelligence and Organizational Commitment between the Hotel Staff in Tehran, Iran. American Journal of Business and Management, 1(2), 54-59. 
Mottaz, C. J. (1987). An Analysis of the Relationship between Work Satisfaction and Organizational Commitment. The Sociological Quarterly, 28(4), 541-558.

Mullins, J. L. (2005). Management and organizational behavior, Seventh Edition, Pearson Education Limited: Essex.

Parvin, M. M., \& Kabir, M. M. N. (2011). Factors Affecting Employee Job Satisfaction of Pharmaceutical Sector . Australian Journal of Business and Management Research, 1(9), 113123.

Porter, L. W., Steers, R. M, \& Mowday, R. T. (1974). Organizational commitment, job satisfaction, and turnover among psychiatric technicians. Journal of Applied Psychology, 59(5), 603-609.

Porter, L. W. \& Lawler, E. E. (1974). “The Effect of Performance on Job Satisfaction.” In Edwin A. Fleishman (ed) Studies in Personal and Industrial Psychology. Third Edition, Illinois.

Robbins \& Stephen, P. (1998). Organizational Behavior: Concept, controversies and Applications. Prentice-Hall.

Samaratunge, R. (2003). Decentralization policies in Sri Lanka: Perceptions and performance. South Asian Journal of Management, 10 (2), 30-43.

Smith, D. \& Cranny, F. (1968). Job Satisfaction, Effort and Commitment. Journal of Business management, 123 (3), 151-164.

Santhapparaj, A. S., \& Alam, S. S. (2005). Job Satisfaction among academic staff in private universities in Malaysia. Journal of Social Sciences, 1(2), 72-76.

Samavi S. A. (2011). Study of Relationship between Job Satisfaction and Organizational Commitment among HighSchool Managers. Journal of Life Sci. Biomed, 1(1), 13-20.

Silverthorne, C. (2004). The impact of organizational culture and person-organization fit on organizational commitment and job satisfaction in Taiwan. Leadership \& Organization Development Journal, 25(7), 592-599.

Smith, P. C., Kendall, L. M., \& Hullin, C. L. (1969). Measurment of satisfaction in the work and retirement. Chicago: Rand McNally.

Spector, P. E. (1997). Job Satisfaction: Application, assessment, cause, and consequences. Thousand Oaks, CA: SAGE Publications, Inc.

Statt, D. (2004). The Routledge Dictionary of Business Mnanagement, 3rd Edition, Detroite: Publishing.

Testa, M. R. (2001). Organizational Commitment, Job Satisfaction and Effort in the Service Environment. Journal of Psychology, 135(2), 226-236.

Thorndike, E. L., \& Barnhart, C. L. (1979). Advanced dictionary. Glenview, IL: Scott, Foresman and Company.

Vandenberg, R. J. \& Lance, C. E. (1992). “Examining the Causal Order of Job Satisfaction and Organizational Commitment. Journal of Management, 18(1), 153-167.

Vedamanickam, J. (2001). Study of Workplace Innovativeness in Manufacturing. Ph.D. Thesis, Sailesh J. Mehta School of Management, Indian Institute of Technology, Bombay.

Vroom, V.H. (1964). Work and Motivation. New York: John Wiley and Sons.

Warr, P, Cook, J., \& Wall. T. (1979). Scales for measurement of some work attitudes and aspects of psychological well being. Journal of Occupational Psychology, 52. 129-148.

Weiss, D. J. Dawis, R. V., England, G. W., \& Lofquist, L. H. (1967). Manual for the Minnesota Satisfaction Questionnaire (Minnesota Studies in Vocational Rehabilitation, No. 22). University of Minnesota, Minneapolis.

Williams, L .J. \& Anderson, S. E. (1991). Job Satisfaction and Organizational Commitment as Predictors of Organizational Citizenship and In-role Behaviors. Journal of Management, 17(3), 601-617.

Young, B. S., Worchel, S. \& Woehr, D. (1998). Organizational Commitment among Public Service Employees. Public Personnel Management, 27(3), 339-348. 